\title{
A study on ectoparasites in Indian Mackerel, Rastrelliger kanagurta (Cuvier, 1817) of Thiruvananthapuram coast, South India
}

\author{
Amrutha Shyla Suresh \\ Postgraduate Department of Zoology and Research Centre, Mahatma Gandhi College, \\ Thiruvananthapuram-695004 (Kerala), India \\ Balamurali Raghavan Pillai Sreekumaran Nair* \\ Postgraduate Department of Zoology and Research Centre, Mahatma Gandhi College \\ Thiruvananthapuram-695004 (Kerala), India \\ Arya Unni \\ Postgraduate Department of Zoology and Research Centre, Mahatma Gandhi College, \\ Thiruvananthapuram-695004 (Kerala), India \\ Binumon Thankachan Mangalathettu \\ Department of Zoology, University of Kerala, Karyavattom, Thiruvananthapuram-695034 \\ (Kerala), India \\ *Corresponding author. E-mail: drbala@mgcollegetvm.ac.in
}

\section{Article Info}

https://doi.org/10.31018/ jans.v13i3.2833

Received: July 7, 2021

Revised: August 28, 2021

Accepted: September 1, 2021

\section{How to Cite}

Suresh, A. S. et al. (2021). A study on ectoparasites in Indian Mackerel, Rastrelliger kanagurta (Cuvier, 1817) of Thiruvananthapuram coast, South India. Journal of Applied and Natural Science, 13(3), 993 - 1002. https://doi.org/10.31018/ jans.v13i3.2833

\begin{abstract}
Parasitic infestation in marine fish requires urgent attention, especially those that infect economically important fishes, which affect their aesthetic quality and palatability. Ectoparasites in Indian Mackerel, Rastrelliger kanagurta (Cuvier, 1817), have not been studied well. Morphological and seasonal study of ectoparasites in $R$. kanagurta from the Thiruvananthapuram coast was conducted during March-August 2018. The study investigated three parasitic groups: Trichodinids, Digenean cysts (Centrocestus Looss, 1899), and Cymothoids (Norileca indica Milne Edwards, 1840 and Nerocila phaiopleura Bleeker, 1857) from $R$. kanagurta during the present study. Of the 240 fishes examined, the Trichodinids and digeneans showed $100 \%$ prevalence on the gill samples. Seasons had no significant effect on trichodinids and digeneans prevalence. However, parasitic Cmothoids fluctuated significantly according to the season. They showed greater prevalence during the pre-monsoon (45\%) and least in monsoon $(25 \%)$ due to environmental parameters like rainfall, salinity, and temperature. Trichodinids parasitized gills of $R$. kanagurta showed increased mucus production, paleness in the gills, and multifocal whitish areas. The Cymothoid infested fish showed lesions with the erosion of the epidermis and underlying dermis at the site of attachment. The noticeable changes were observed in the gill epithelium due to the encystment of digeneans. The Trichodinid ciliates and Heterophyid digenean cysts (Centrocestus Looss, 1899) are reported for the first time in R. kanagurta.
\end{abstract}

Keywords: R. kanagurta, Trichodinids, Digeneans, N. indica, N. phaiopeura

\section{INTRODUCTION}

Parasitic fish diseases are one of the most serious issues in the fisheries sector (Sethi et al., 2013). The fish parasites were ranging from microscopic protozoans to easily visible crustaceans and annelids. Some of them are parasitic in the external surface of fish, and others are parasitic in the internal organs. The effects of parasites on different host species may differ (Roberts, 2012). Parasites interfere with the nutrition, metabolism, and secretory function of the alimentary canal, damage the nervous system and upset the host's normal reproduction. Besides direct losses, parasites may have a considerable impact on the behaviour of fish, reduced fecundity, their resistance to other stressing factors, susceptibility to other infections, the potential legislative burdens, and their presence may also reduce the marketability of fish (Paladini et al., 2017). Ectoparasite infestation is one of the most hazardous threats to fish health. It causes low body weight gain, high mortality, and poor marketability due to skin and gill abrasions that promote opportunistic microorganisms invasion (Eissa, 2002).

The Indian mackerel, Rastrelliger kanagurta, consti- 
tutes an important commercial fisheries species in countries bordered with the Indian Ocean, Indonesia, Pakistan, India, Sri Lanka, Bangladesh, Myanmar, Thailand (Jayabalan et al., 2014). The Indian mackerel constitutes a prominent group in the landings of both the Arabian Sea and the Bay of Bengal (Goutham and Mohanraju, 2015), with a significant increase in the annual landings of Indian mackerel along the Indian coast. An average annual catch in the country was estimated to be 0.16 million tonnes (CMFRI, 2019).

The available information deals with reports of parasite species in $R$. kanagurta belonging to Monogenea, Digenea, and Crustacea (Madhavi and Triveni Lakshmi, 2011; Rameshkumar and Ravichandran, 2010). Madhavi and Triveni Lakshmi (2011) reported the metazoan parasite fauna of the fish from the Visakhapatnam coast, Bay of Bengal and discussed its role as a host different species of metazoan parasites. Later, Madhavi and Triveni Lakshmi (2012) studied the community ecology of the metazoan parasites of the $R$. kanagurta. Recently, seasonal variation in the prevalence of cymothoid isopod, Norileca indica, was studied by Jemi et al., 2020). There have been no studies on the distribution and infestation of ectoparasites in $R$. kanagurta.

Accurate identification and changes in the occurrence of ectoparasites in these fishes are important due to their food value, consumer preference and availability in the market. Hence, this study aimed to identify major ectoparasites in Indian mackerel, $R$. kanagurta collected from fish landing centres of Thiruvananthapuram coast, South India.

\section{MATERIALS AND METHODS}

\section{Fish species and sampling}

Samples of Indian mackerel, Rastrelliger kanagurta were collected from major harbours of the Thiruvananthapuram coast -Perumathura (Longitude: E. 76 48'0.03", Latitude: N. $\left.8^{0} 37^{\prime} 30.59^{\prime \prime}\right)$ and Vizhinjam (Longitude: E. 76 59'15”, Latitude: N. 8²2'30”) during the period from October 2017 to September 2018 for parasitological analysis. The fish were collected from commercial fishing harbours caught by local fishermen to investigate parasite infestation. Thus, the animals used in this study (fish/parasites) did not require ethical committee approval for the present work. The collected fishes were transported to the laboratory and were examined immediately. A total of 240 fish with an average total length of 13 to 16 were used for this study.

\section{Seasonal analysis}

Monthly collection of 20 fish each was done for each pre-monsoon (February-May), monsoon (JuneSeptember), and post-monsoon (October-January) season. Prevalence and mean intensity of infestation of
Trichodinids, Cymothoids and digenea cysts in relation to the month of the collection were calculated (Margolis et al., 1982).

\section{Parasitological examination}

Each fish was examined thoroughly and carefully for the presence of parasites after measuring length and weight. The methods suggested by Kennedy (1977) were adopted for parasitological studies. The location of the site of interaction and the number and types of parasites in each site of interaction was noted. Skin scrapings from different regions of the body were examined under the high power of Transmission Light Microscope (TLM) (Optika Microscope; Optikam B5 Digital Camera) for the possible presence of ectoparasites. The buccal cavity was also subjected to thorough microscopical examination. After completing the external examination, the operculum on either side was taken out, and their inner sides were thoroughly examined. Gills from the blind and ocular sides were excised and transferred to separate Petri dishes containing $0.65 \%$ saline.

\section{Processing of protozoans}

Thin slides were prepared for microscopic ciliate protozoan parasites from the skin and gill scrapings of the fish. The slides were stained according to Klein's dry silver impregnation method (Klein, 1958). The slides were air-dried and covered with a $2 \%$ aqueous solution of silver nitrate $\left(\mathrm{AgNO}_{3}\right)$ for 8 minutes. After that, rinse the slides thoroughly in distilled water and exposed to direct sunlight for 1-2 hr. The slides were then allowed to dry and mount with DPX mountant.

\section{Processing of digeneans}

Gill examinations for the presence of digenean cysts were carried out under Stereo Dissecting Microscope (SDM) (Carl Zeiss Microscopy; GmbH Stemi 508) according to the methods suggested by Madhavi (2006). Encysted digeneans were carefully dissected under TLM to release the contained digenean parasite. After that, they were stained in Gower's Carmine (Roberts, 1978). Stained materials were mounted in D. P. X.

\section{Processing of cymothoids}

Cymothoids encountered during the examination were carefully isolated and cleaned off mucus and other debris adhering to their bodies and preserved in $10 \%$ neutral buffered formalin. The general morphological features of the parasites were studied by using a hand lens and cleared in 50\% lactic acid. Taxonomically important body parts such as pereopods, pleopods, uropod and mouthparts were carefully dissected out under SDM according to the techniques described by Aneesh et al. (2019). 


\section{Photographs}

The photomicrographs of trichodinids and digeneans were taken under TLM. Taxonomic drawings of isopods were made using a drawing tube attached to TLM and the computer programme CorelDraw Version 14. The photographs of isopods were taken using Canon EOS $800 \mathrm{D}$ with a $35 \mathrm{~mm}$ macro lens.

Trichodinids, Digeneanss and Cymothoids (Norileca indica and Nerocila phaiopleura) were identified using the taxonomic keys of Reichenbach-Klinke and Elkan (1965); Chauhan (1953); and Bruce (1987 and 1990), respectively. All the linear measurements are represented in micrometres for protozoan parasites. For metazoan parasites, the measurements are represented in micrometres as well as millimetres.

\section{RESULTS}

In the present study, it was observed that the Trichodinid ciliates were present in the scrapings from the body surface, buccal cavity, and gills of $R$. kanagurta. Digenean cysts were observed attached to the gill epithelium. Cymothoids were found to be present on the body surface, mouth, opercular cavity and gills.
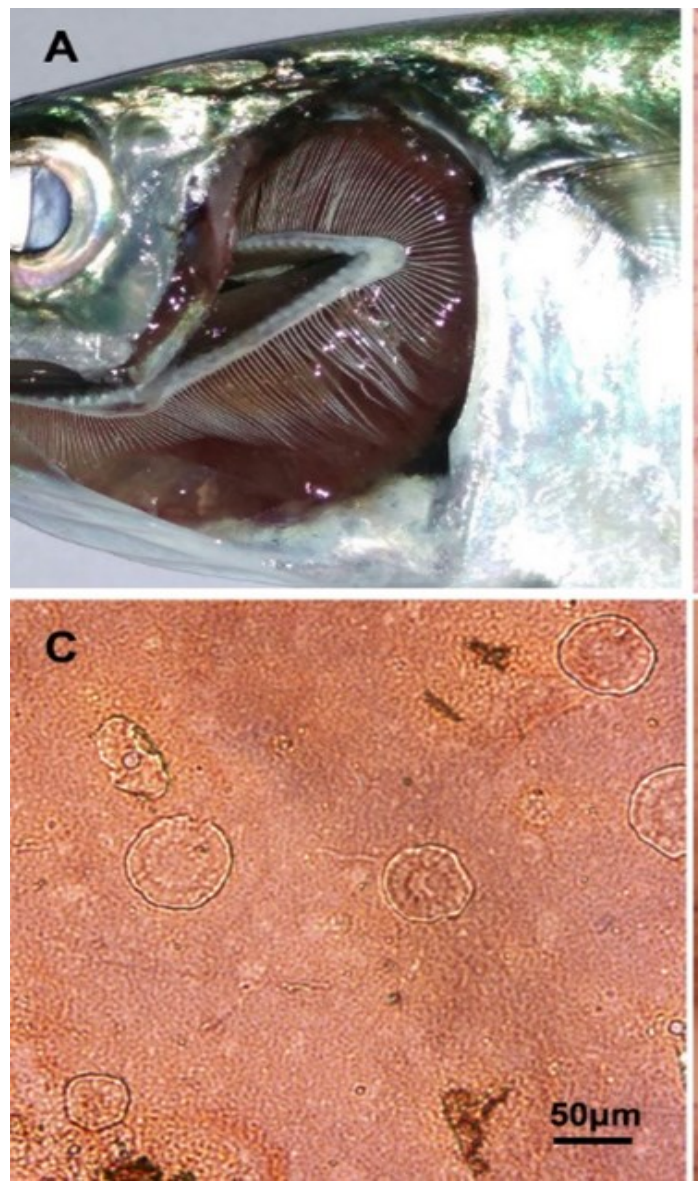

Taxonomic description of the ectoparasites in $R$. kanagurta

Trichodinids (Mobilidae: Trichodinidae)

Taxonomic description (8 specimens studied, all measurements are in microns): A flat disc-shaped body having a diameter of $275.76 \mu \mathrm{m}$ with rows of cilia at the

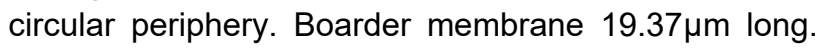
Adhesive disc concave, surrounded by fine striated border membrane. The lightly stained central area of the adhesive disc presents, which helps attach firmly to the fish skin or gills. Adhesive disc $148.80 \mu \mathrm{m}$ in diameter. Denticular ring present with denticles. Denticular ring $98.10 \mu \mathrm{m}$ in diameter. The denticle spans $31.18 \mu \mathrm{m}$ in width. The denticle blade had a length of $11.55 \mu \mathrm{m}$, Central area and ray were visible. The central part was $37.92 \mu \mathrm{m}$ wide and Ray $9.49 \mu \mathrm{m}$ long (Fig. 1B-D).

\section{Cymothoids (Isopoda: Cymothoidae) \\ Norileca indica}

Taxonomic description of the female (10 specimens studied): Body asymmetrical, oblong, pale creamy, the dorsal surface highly convex, eyes dark and distinct. Body about 2.4-2.5 times wide, twisted to one side; widest at pereonite 4; dorsum moderately convex.
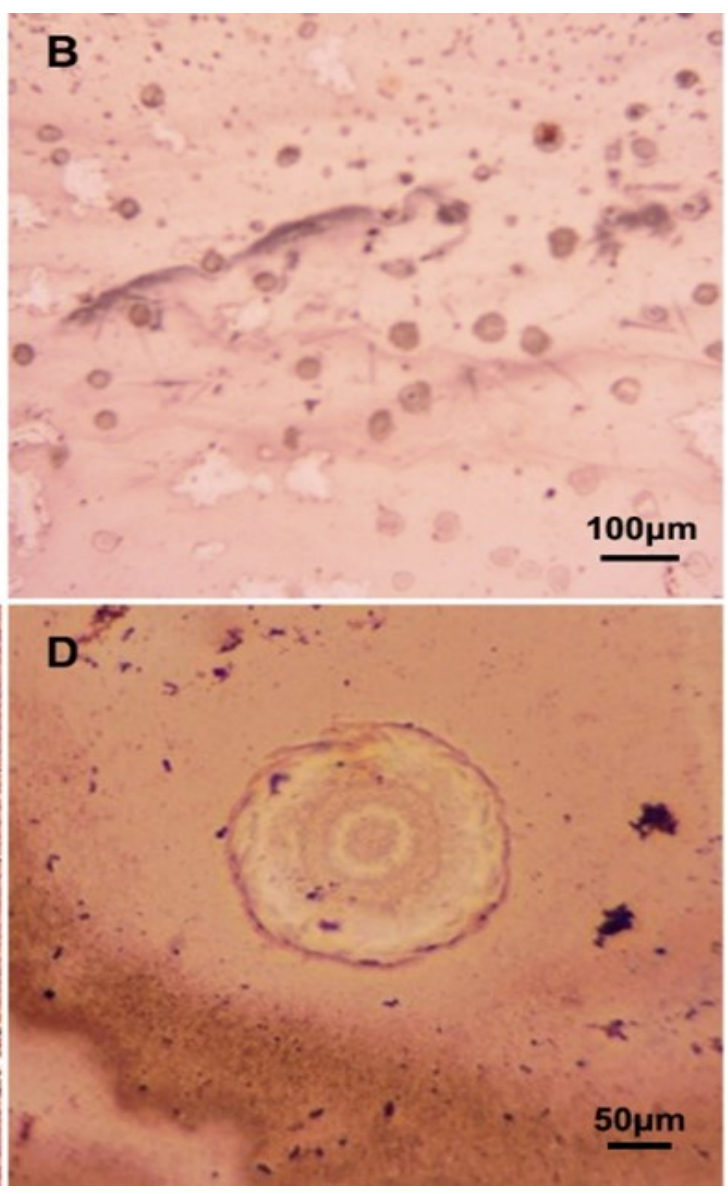

Fig. 1. R. kanagurta parasitised by Trichoinid ciliates. A) Gill filaments of the infested fish showing increased mucus production and paleness. $B-D)$ Photomicrographs showingf Klein's silver-impregnated specimens of Trichodinids from the gill smears- Magnification $X 100, X 40$ and $X 10$ respectively. 
Cephalon not deeply immersed in pereonite 1 , interior margin sub truncate; eyes $0.47-0.52$ width of the cephalon. Pereonite 1 with posterolateral angles weakly produced. Coxae of pereonite 2 as long as the segment; coxae of pereonites 3-7 all about 0.8 as long as the respective segment. Posterior margin of pereonite 7 weakly concave. Pleon $0.66-0.74$ width of pereonite 4 , with all segments about as wide as pereonite 7 , pleonite 5 as wide as pleonite 1 ; lateral margins posteriorly directed. Pleotelson triangular, anteromedial surface vaulted. Antennule extends to pereonite 1 , bases set wide apart, composed of 8 articles; antenna is slightly longer than antennule, with 9 articles (Fig. 1B).

Mandible with large palp, article 2 flattened, expanded; article 30.35 as long as article 2. Maxilliped article 3 with 4 large recurved spines. Pereopod 1 ischium 0.69 lengths of basis; dactylus is curving abruptly at about proximal 0.2 of its length, extending to anterior of the carpus, which has a recess that receives dactylus apex. Pereopods 2 and 3 alike 1 but slightly longer. Pereopods 4-7 similar to each other; pereopod 7 ischium 1.03 length of basis, dactylus extends to posterior of carpus with a recess that receives dactylus apex; propodal palm with 2 small spines. Uropods about 0.55 -0.60 length of pleotelson, rami subequal in length, apices rounded; endopod slightly tapered (Figs. $1 \mathrm{D}-\mathrm{G}$ ).

\section{N. phaiopleura Bleeker, 1857}

Taxonomic description of the female: Eyes large, about 0.5 widths of the cephalon. Pleonites 1 and 2 with ventrolateral margins weakly times longer than article 2 . Lateral margin with about 22 stout setae. Maxilliped article 3 with 4 recurved spines. Pereopods 1-5 with weak swelling on anteroproximal margin of dactylus; pereopod 7 with 2 spines on posterior margin of propodus. Uropod slender, tapering exopod, 1.7-2.1 times longer than endopod; endopod apex narrowly rounded or obliquely truncate (Figs. $3 \mathrm{C}-\mathrm{H}$ ).

\section{Digenean cysts (Trematoda: Heterophyidae) \\ Metacercariae of Centrocestus spp. (Looss, 1899)}

Metacercariae of Centrocestus spp. were released from the cyst attached in the gill epithelium of $R$. kanagurta (Figs. 4 A-C).

\section{Taxonomic description}

Body (0.308-0.328 x 0.08-0.12) somewhat elongate, narrower in the extreme anterior end, pitcher shaped and covered with small cuticular spines up to the extreme posterior end. Oral sucker $(0.026 \times 0.04)$ large and terminal. Spines on the outer surface surround these suckers. The posterior sucker $(0.0187)$ was small round and situated in the posterior half of the body. Oe-
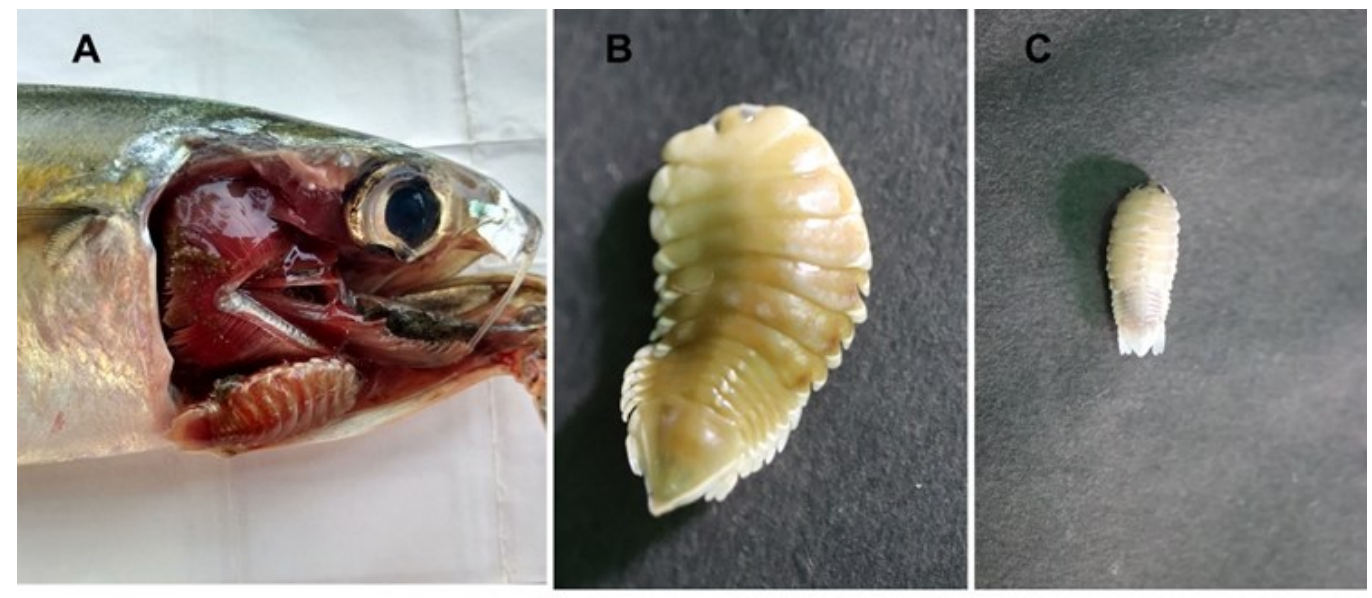

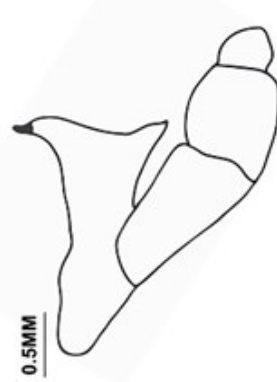

D

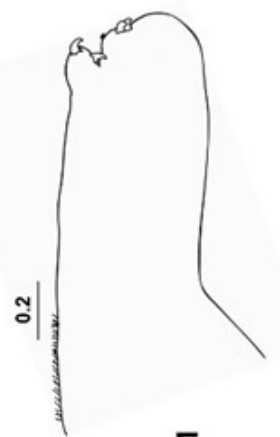

E

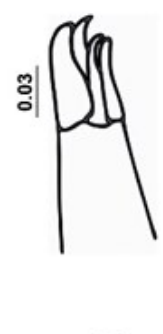

$\mathbf{F}$

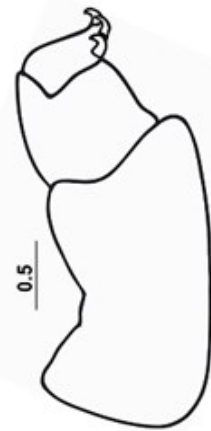

G

Fig. 2. N. indica infestation on R. kanagurta. A) Parasite attached on the buccal cavity of the fish. B) N. indica Female C) Male, D) Mandible, E) Maxilla, F) Maxillule, G) Maxilliped. 

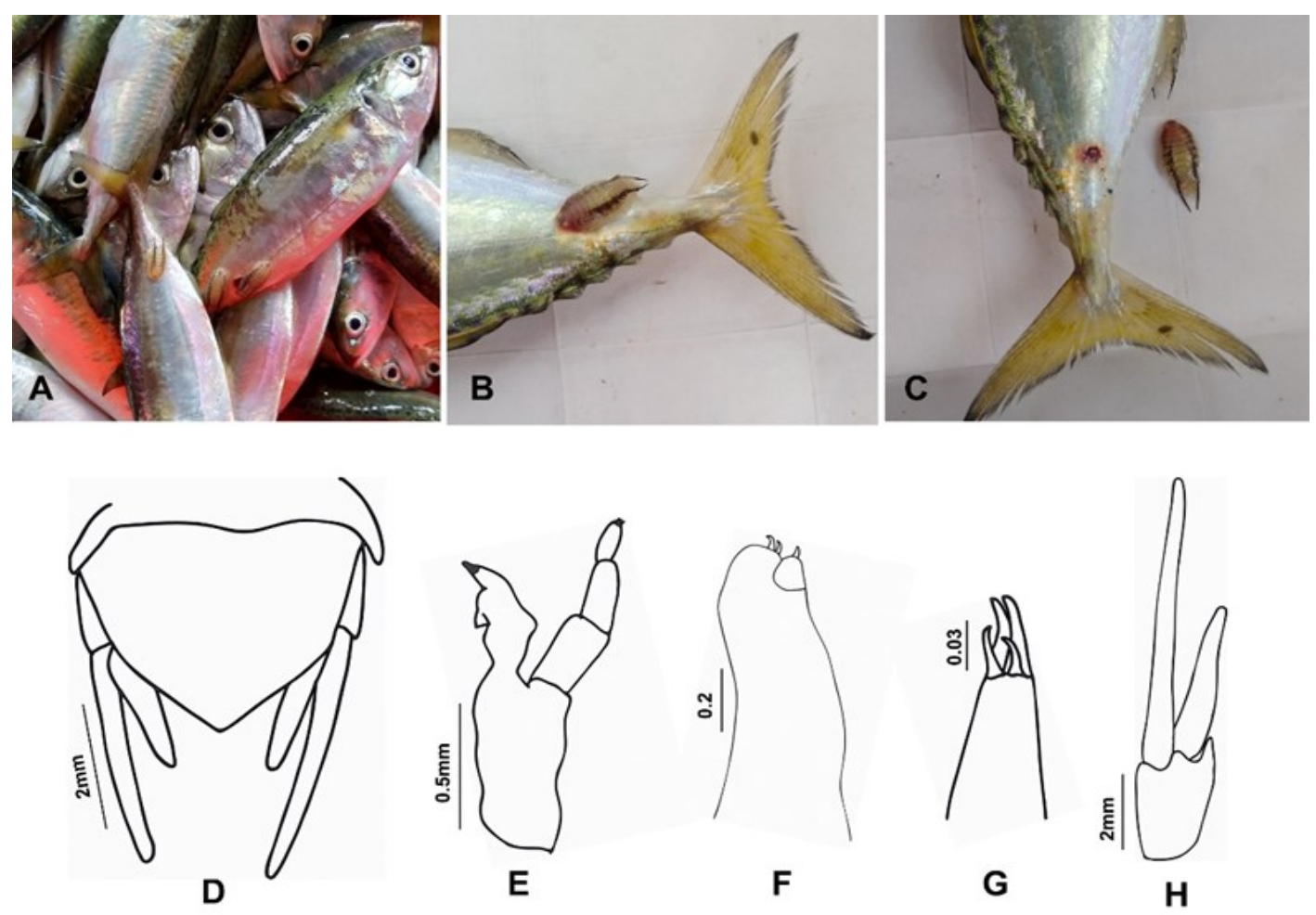

Fig. 3. N. phaiopleura infestation on R. kanagurta. A\&B) Parasite attached on the posterior body surface of the fish. C) Large hemorhagic wound made by the parasite on the fish. D) Pleotelson, dorsal view. E) Mandible F) Maxilla G) Maxillule H) Uropod.

sophagus (0.051-0.0457) long, slender. Pharynx small, at about $1 / 4$ distance from anterior end. Bifurcation of ceca at about one-third distance from anterior end. Ceca long (0.194-0.205), extending up to the posterior end of the body. Reproductive organs were rudimentary and situated at the extreme posterior end. Excretory bladder nearly ' $X$ 'shaped (Fig. 4D).

\section{Nature of infestation of the ectoparasites in $R$. kanagurta}

There was no seasonal variation in the prevalence of Trichodinids and digenean cysts. These parasites showed $100 \%$ prevalence in all the seasons. Eighty $R$. kanagurta specimens were examined for each season, and all of them were infested with Trichodinids and digenean cysts. Trichodinid parasitizing the gills of the fish showed increased mucus production, paleness in the gills, and multifocal whitish areas (Fig. 1A). The parasites were in permanent rotation while attached to a host, which irritated the epithelial cells.

Seasonal variations in the rate of infestation of $N$. indica were observed (Table 1). The prevalence of parasitic Cymothoids fluctuated significantly according to the season. Out of 80 specimens of $R$. kanagurta examined, 36 were infested during pre-monsoon, 20 fishes were infested during monsoon, and 26 were infested during post-monsoon. A significant increase was observed in Isopods during pre-monsoon (45\%) and showed a decrease during monsoon (25\%). The highest prevalence of the parasite was observed during March (50\%) and the least in September (20\%).

The mouth and gills (Fig. 2A) were the major sites of attachment for $N$. indica. In the parasitized fish, lesions with the erosion of the epidermis and underlying dermis were observed at the site of parasite attachment. Juveniles; males (Fig. 2C); transitionals; non-brooded ovigerous females; and Brooded ovigerous females carrying marsupiumites (Fig. 2B) of $N$. indica were recovered from the fish. The posterior body surface was the preferred site for N. phaiopleura (Fig. 3A and B), and it showed site-specificity in the host. Large haemorrhagic wound/ulceration was observed at the parasite attachment site (Fig. 3C). Out of 80 specimens of $R$. kanagurta examined, 30 were infested by $N$. phaiopleura. Brooded ovigerous females and transitionals of $N$. phaiopleura were recovered during the present study.

\section{DISCUSSION}

The study based on the examination of $R$. kanagurta collected as monthly samples from the Thiruvananthapuram coast (Arabian Sea) revealed the fish's protozoan and metazoan parasite fauna was fairly rich, comprising of trichodinids, digeneans, and Isopods.

Trichodinid ciliates are geographically a widely dispersed group of ectoparasites in all the aquatic environ- 
Table 1. Seasonal occurrence of Cymothoids (N. indica) in R. kanagurta during October, 2017-September, 2018.

\begin{tabular}{|c|c|c|c|c|c|c|c|c|c|c|c|c|}
\hline \multirow{2}{*}{$\frac{\text { Season }}{\text { Month }}$} & \multicolumn{4}{|c|}{ Post-monsoon } & \multicolumn{4}{|c|}{ Pre-monsoon } & \multicolumn{4}{|c|}{ Monsoon } \\
\hline & Oct. & Nov. & Dec. & Jan. & Feb. & Mar. & Apr. & May & Jun. & Jul. & Aug. & Sep. \\
\hline No. of fish examined & 20 & 20 & 20 & 20 & 20 & 20 & 20 & 20 & 20 & 20 & 20 & 20 \\
\hline No. of fish infected & 6 & 6 & 7 & 7 & 8 & 10 & 9 & 9 & 6 & 5 & 5 & 4 \\
\hline Prevalence (\%) & 30 & 30 & 35 & 35 & 40 & 50 & 45 & 45 & 30 & 25 & 25 & 20 \\
\hline Average & \multicolumn{4}{|c|}{$33 \%$} & \multicolumn{4}{|c|}{$45 \%$} & \multicolumn{4}{|c|}{$25 \%$} \\
\hline
\end{tabular}
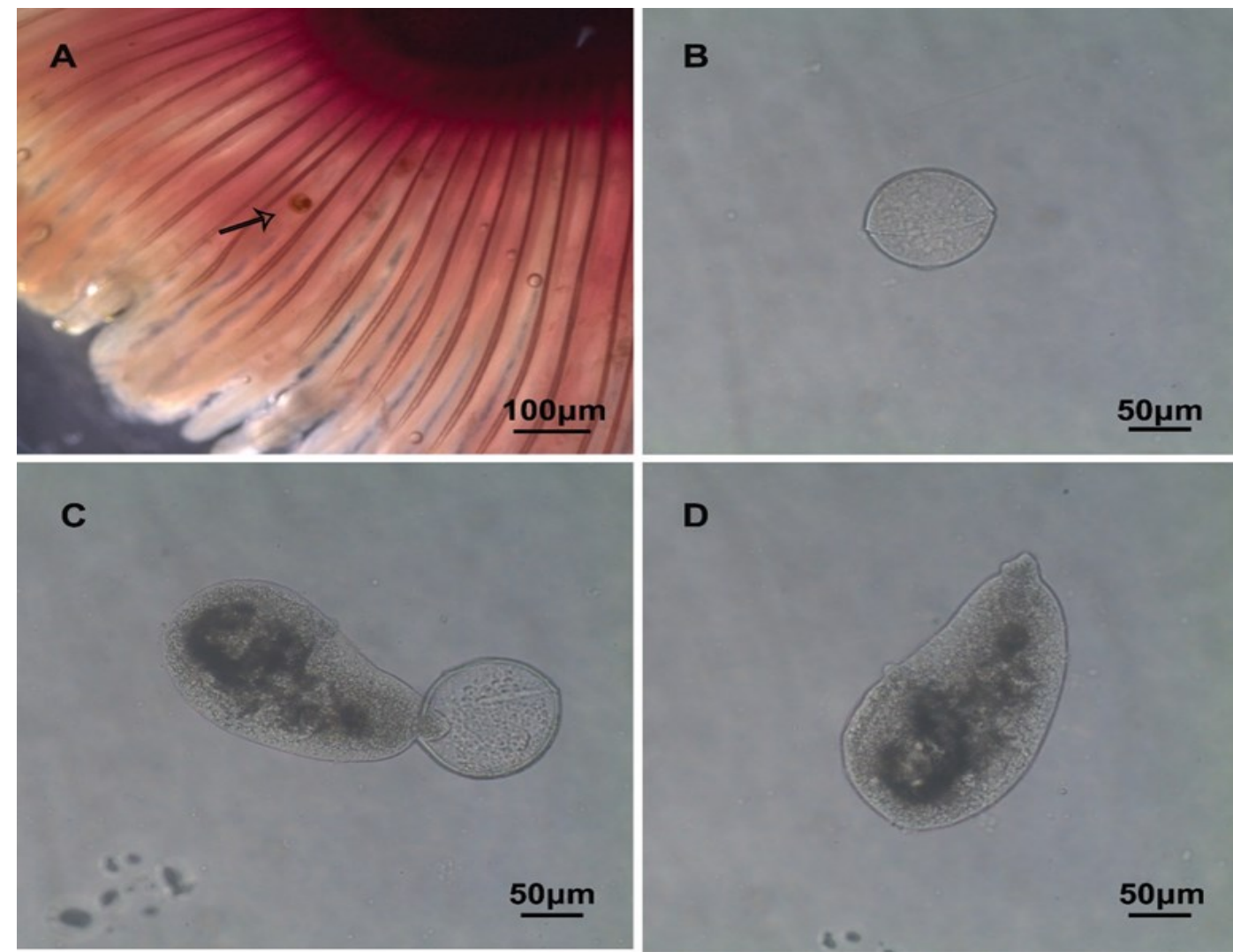

D

Fig. 4 (A-D). Digenean infestation on R. kanagurta. A) Digenean cyst in the gill of the fish (Magnification X 8). B) Digenean cyst (Magnification X 40). C) Metacercaria of Centrocestus (Looss, 1899) releasing from the cyst (Magnification X 40). D) Metacercariae of Centrocestus (Magnification X 40)

ments- freshwater, marine and euryhaline environments. Trichodinids are probably the most common protozoan parasites found in many other fishes from different parts of the world (Tantry et al., 2016).

Isopods reported from $R$. kanagurta in this study belonged to the family Cymothoidae (Leach, 1814), which represent the largest family of parasitic isopods infesting several fish species of economic importance, as reported by Ravichandran et al. (2019). Digeneans are also a common group of fish parasites and are reported from $R$. kanagurta so far from different parts of the world (Al-Zubaidy and Mhaisen, 2014; Madhavi and Triveni Lakshmi, 2011).

In the present study, the seasonal analysis revealed that the trichodinids and digeneans cysts showed a $100 \%$ prevalence over other parasites. This higher occurrence of these species may be due to the selection of larger sized fishes for the present study. According to Ozer and Erdem (1998), the severity of most parasitic infections increases with the age of the host fish, possibly due to the greater accumulation period and the larger space for feeding and breeding of the parasite. In a study of Trichonia spp. on the ornamental fishes of West Bengal, Saha and Bandyopadhyay (2017) stated that the biological factors, as well as environmental factors of the host, may play a pivotal role in the outbreak of protozoans. Xu et al. (2002) reported that the factors like pollution and stress, which lowered the host's immune response, may also result in the proliferation of the parasite.

In the present study, the seasonality effect on trichodinid infestation and digenean cysts had no significant impact on parasite prevalence, similar to the work of Suliman et al. (2021) who reported the higher prevalence of trichodina on Oreochromis niloticus in the fish farms of Saudi Arabia in all seasons. Bo-ping and 
Xianghua (2000) report that the prevalence, mean intensity and relative density of metacercarial cyst infrapopulation of Centrocestus formosanus on the gills of grass carps Ctenopharyngodon idellus were not obviously correlated with the seasonal change of water temperature. In a study of metacercarial distribution of C. formosanus (Digenea: Heterophyidae) among fish hosts in the Guadalupe River drainage of Texas, Fleming et al., 2011 found that these digenean cysts showed $100 \%$ prevalence in the fishes, Cyprinella lutrensis, Dionda nigrotaeniata and Ameiurus natalis.

Season dependent variation was noticed in the intensity and prevalence of parasitic Cymothoids from $R$, kanagurta during the present study period (Table 1). Norileca indica showed greater prevalence during the pre-monsoon and least in monsoon season in this study. The prevalence could be dependent on environmental parameters like rainfall, salinity, and temperature. According to Aneesh et al. (2013), parasitic cymothoids' prevalence and mean intensity depend on the environment's seasonal variation. Higher prevalence in pre-monsoon during the present investigation may be due to the effect of increased salinity. Our findings support the work of Kottarathil et al. (2019), who suggested that higher salinity favours the isopod parasitization of fish which might be favourable for the parasite to infect its host fish. The low prevalence observed during the monsoon period in our study may be due to the weak salinity resulting from the heavy rainfall, inducing an unfavourable environment for the parasitic infestation. In a study on Nerocila spp. parasitized marine fishes of the Malabar Coast, India, Aneesh et al. (2013) corroborated with our findings. An increase in the infestation of the parasites from post-monsoon to pre-monsoon was observed during the study. The gradual increase in salinity during the post-monsoon season seems to facilitate the more parasitic infestation. Still, the exact mechanism by which the salinity plays a role in the parasitization is unclear, and a detailed and systematic experimental study is needed to confirm this. al. 2005).

In the present study, the skin of trichodinid parasitized fish showed a change in body colouration and excessive production of mucus. The body of the host fish was observed dull with a thin film of mucus. Woo (2006) suggested that the clinical signs of trichodinid infestation most commonly observed were a mottled/grey appearance on the skin (caused by the excessive production of the mucus) in a study of Trichodina infestation on the skin of Tilapia. In the present study, Trichodinid parasitizing gills of $R$. kanagurta showed increased mucus production, paleness in the gills along with multifocal whitish areas (Fig. 1A). Valladao et al. (2013) found mucous production, paleness and multifocal whitish areas in the severely infested gills of Nile tilapia by
Trichodinid, Paratrichodina africana. Complete fusion of the secondary lamellae, proliferation of mucous cells, mononuclear and eosinophilic inflammatory infiltrate, multifocal areas of necrosis, congestion, and desquamated cells may be the reason for these changes observed. These parasites attack the fish and cause massive destruction of the skin and gill epithelium (Sterud et al., 2008). Outbreaks and mass mortality of Atlantic cod (Gadus morhua) infested with Trichodina murmanica infection was reported in a coastal embayment of Newfoundland (Khan, 2004).

In the present study, digeneans were observed as cysts attached to the gill epithelium, and changes were noticed in the gill epithelium of the host (Fig. 4A). The changes that occurred in the gills could be due to epithelial hyperplasia and fusion of the filaments. Mitchell et al. (2000) studied heterophyid trematode infecting the gills of an endangered fish, the Fountain darter, Etheostoma fonticola, in two Central Texas spring-fed rivers. They found that digenean cyst infected gill filaments of the fish were shortened, thickened, and often distorted. Ravichandran and Rameshkumar (2012) studied the gill-infecting Didymozoid in fishes of Pazhayar, India and reported that the most common effect of digenean cyst on affected fish are epithelial cells on gill lamellae, damage to gill epithelium and thus respiration is affected. They also suggested that heavily infested digenean parasitized fish were often weak, thin, inactive, and fed poorly. According to Mitchell et al. (2005), metacercariae encysted in gills causes pathological alterations related to developmental delay and death, giving rise to economic losses in the fish farming industry.

Cymothoid infested fishes in this study showed damage to gills (Fig. 3A), skin (Fig. 3C), and tongue. During the study, lesions with the erosion of the epidermis and underlying dermis were observed at the site of parasite attachment in the $N$. indica parasitized fish. The result of the present study is corroborated with the study of Rameshkumar et al. (2013), who reported localized destruction of the epidermis and an inflammatory response around the site of attachment of Cymothoid, Catoessa boscii in Carangoides malabaricus from Tamil Nadu, India. In the present study, the gills of $R$. kanagurta were damaged due to the attachment of Cymothoid $N$. indica (Fig. 3A). While studying the effect of the Cymothoid, Joryma hilsae, on the branchial area of Stolephorus commersonii, Ravichandran and Rameshkumar (2014) suggested that erosion of gill lamellae, damage to gill rakers, and pale gills were the significant gross lesions found as a result of isopod infestation. In our study, large haemorrhagic wound/ ulceration was observed on the body surface of $R$. kanagurta infested by $N$. phaiopleura (Fig. $3 C$ ). It is also reported that $N$. phaiopleura cause skin damages in a 
variety of fish species, including Dussumieria acuta (Ravichandran and Rameshkumar, 2014), Thunnus orientalis (Nagasawa and Shirakashi, 2017a) and Sardinops melanostictus (Nagasawa et al., 2020). In the present investigation, the damages in the body surface, buccal cavity and branchial cavity may be due to the feeding and the pressure exerted by the parasite on the host. The posterior body surface was the preferred site for attachment for the parasite N. phaiopleura (Fig. 3B), and it showed site-specificity in the host. In a study on Nerocila spp. from Indian marine fishes, Trilles et al. (2013) reported that body surface is the preferred attachment site for $N$. phaiopleura.

The Indian mackerel constitutes a prominent group in the landings of both the Arabian Sea and the Bay of Bengal (Goutham and Mohanraju, 2015). Different types of parasites found on the fish $R$. kanagurta during the present study indicate that Indian mackerel from the Thiruvananthapuram coast appear to be a potential host for these parasites. Considering the wide geographical distribution and host range of the trichodinids (Tantry et al., 2016), Heterophyid Digeneans (Gamit et al., 2018) and Cymothoids (Nagasawa and Isozaki, 2017b), these parasites have the potential to become a threat to coastal farming also. The Cymothoid, N. phaiopleura, is also reported to facilitate secondary microbial infections in fishes (Ravichandran et al., 2016). Fishborne Heterophyid Digeneans are known to have a zoonotic potential (Chai and Jung, 2017). Thus, adequate management measures, including chemical Indian mackerel prophylaxis, are needed to control the infection of these parasites to some extent in coastal farming.

\section{Conclusion}

The present study revealed that the Indian mackerel $R$. kanagurta is a potential host for three major parasitic groups, namely Trichodinids, Digeneans cysts (Centrocestus spp.) and Cymothoids (Norileca indica and Nerocila phaiopleura). The Trichodinids and digeneans showed $100 \%$ infestation in all the seasons. In contrast, seasonal fluctuation was observed in the prevalence of parasitic isopods. The Trichodinid infestation resulted in increased mucus production, paleness in the gills, and multifocal whitish areas. The encystment of digeneans in the gills of the fish also resulted in significant changes. In the Cymothoid infested fish, lesions with the erosion of the epidermis and underlying dermis were observed at the site of attachment. The parasites may induce damages to the attachment sites, thus harming the host's physiological status. A heavy infestation can affect the commercial value of fish. The Trichodinid ciliates and heterophyid digenean cysts of Centrocestus spp. are reported for the first time from the gills of $R$. kanagurta from the world.

\section{ACKNOWLEDGEMENTS}

The authors acknowledge Dr B Santhosh, Principal Scientist, Central Marine Fisheries Institute, Vizhinjam, Thiruvananthapuram, for supporting research work. We acknowledge Dr Aneesh P T, UGC- DS Kothari PostDoctoral Fellow, Deptartment of Aquatic Biology \& Fisheries, University of Kerala, for the constant support. We thank the University of Kerala for providing $\mathrm{Re}$ search Grant (AcE VI/117/ZOO/15059/2017).

\section{Conflict of interest}

The authors declare that they have no conflict of interest.

\section{REFERENCES}

1. Al-Zubaidy, A. \& Mhaisen, F. (2014). Four new records of trematodes from the Indian mackerel Rastrelliger kanagurta (Cuvier, 1816) from the Yemeni coastal waters of the Red Sea. American Journal of Biology and Life Sciences, 2(6), 141-145.

2. Aneesh, P.T., Helna, A.K., Trilles, J.P. \& Chandra, K. (2019). A taxonomic review of the genus Joryma Bowman and Tareen, 1983 (Crustacea: Isopoda: Cymothoidae) parasitizing the marine fishes from Indian waters, with a description of a new species. Marine Biodiversity. 49(1), 1449-1478. doi.org/10.1007/s12526-017-0799-8

3. Aneesh, P.T., Sudha, K., Arshad, K., Anilkumar, G. \& Trilles, J.P. (2013). Seasonal fluctuation of the prevalence of cymothoids representing the genus Nerocila (Crustacea, Isopoda), parasitizing commercially exploited marine fishes from the Malabar Coast, India. Acta Parasitologica, 58(1), 80-90. doi.org/10.2478/s11686-013-0112-3

4. Bo-ping, Z. \& Xianghua, L. (2000). Monthly changes of the metacercarial cyst infrapopulation of Centrocestus formosanus (Nishigori, 1924) on the gills of grass carps Ctenopharyngodon idellus. Acta Hydrobiologica Sinica, 24(2), 137-142. Retrieved Aug. 06, 2021. https://www.cabi.org/ isc/abstract/20000807252

5. Bruce, N.L. (1987). Australian species of Nerocila Leach, 1818, and Creniola n.gen. (Isopoda: Cymothoidae), crustacean parasites of marine fishes. Records of the Australian Museum, 39(6), 355-412. doi.org/10.3853/j.00671975.39.1987.174

6. Bruce, N.L. (1990). The genera Catoessa, Elthusa, Enispa, Ichthyoxenus, Idusa, Livoneca and Norileca n.gen., (Isopoda, Cymothoidae), crustacean parasites of marine fishes, with descriptions of eastern Australian species. Records of the Australian Museum, 42(3), 247-300. doi.org/10.3853/j.0067-1975.42.1990.118

7. Central Marine Fisheries Research Institute (CMFRI) (2019). Estimated marine fish landings in India during 2019. Annual National Data for 2019. Retrieved June 20, 2021, https://www.cmfri.org.in/2019

8. Chai, J.Y. \& Jung, B.K. (2017). Fishborne zoonotic heterophyid infections: an update. Food Waterborne Parasitol, 8 
(9), 33-63. doi.org/10.1016/j.fawpar.2017.09.001

9. Chauhan, B.S. (1953). Studies on the trematode fauna of India. Part III Subclass Digenea (Gasterostomata). Records of the Indian Museum, 51(2), 231-287. Retrieved July $8, \quad 2021$, https://www.cabdirect.org/cabdirect/ abstract/19530802360

10. Eissa, I.A.M. (2002). Parasitic fish diseases in Egypt. Dar El-Nahdda El-Arabia publishing.

11. Fleming, B.P., Huffman, D.G., Bonner, T.H., Brandt, T.M. (2011). Metacercarial distribution of Centrocestus formosanus among fish hosts in the Guadalupe River drainage of Texas. Journal of Aquatic Animal Health, 23(3), 117-24. doi.org/10.1080/08997659.2011.616840

12. Gamit, A.B., Nanda, P.K., Bhar, R., Bandyopadhyay, S. \& Bandyopadhyay, S. (2018). A Report of Centrocestus formosanus (Nishigori, 1924) (Digenea: Heterophyidae) in Intermediate Host (Fish). International Journal of Current Microbiology and Applied Sciences, 7(7), 928-936. doi.org/10.20546/ijcmas.2018.707.112

13. Goutham, J., Mohanraju, R. (2015). Some aspects of mackerel diversity and morphometric studies of Rastrelliger genera from Port Blair Andaman waters. International Journal of Fish and Aquatic Studies, 3(1), 196-198. Retrieved July 7, 2021. https://www.fisheriesjournal.com/ archives/2015/vol3issue1/PartC/2-6-19.pdf

14. Jayabalan, N., Zaki, S., Al-Kiyumi, F. \& Al-Kharusi, L. (2014). Age, growth and stock assessment of the Indian mackerel Rastrelliger kanagurta (Cuvier, 1817) along the Sohar coast of Oman. Indian Journal of Fisheries, 61(1), 1 -6. Retrieved January 18, 2021. http://epubs.icar.org.in/ ejournal/index.php/IJF/article/view/26468

15. Jemi, J.N., Hatha, A.A.M. \& Radhakrishnan, C.K. (2020) Seasonal variation of the prevalence of cymothoid isopod Norileca indica (Crustacea, Isopoda), parasitizing on the host fish Rastrelliger kanagurta collected from the Southwest coast of India. Journal of Parasitological Diseases, 44 (2), 314-318. doi.org/10.1007/s12639-020-012 08-6

16. Kennedy, C.R. (1979). The distribution and biology of the cestode Eubotbrium parvum in Capelin, mallotus villosus, (Pallas) in the Barents Sea, its use as a biological tag. Journal of Fish Biology, 15, 223-236. doi.org/10.1111/ j.1095-8649.1979.tb03585.x

17. Khan, R.A. (2004). Disease outbreaks and mass mortality in cultured Atlantic cod, Gadus morhua L., associated with Trichodina murmanica (Ciliophora). Journal of Fish Diseases, 27(3), 181-184. doi.org/10.1111/j.1365-2761.200 4.00525.x

18. Klein, B.M. (1958). The dry silver method and its proper use. Journal of Parasitology, 5(2), 99-103. doi.org/10.1 111/j.1550-7408.1958.tb02535.x

19. Kottarathil, H.A., Sahadevan, A.V., Kattamballi, R. \& Kappalli, S. (2019). Norileca indica (Crustacea: Isopoda, Cymothoidae) infects Rastrelliger kanagurta along the Malabar coast of India - Seasonal variation in the prevalence and aspects of host-parasite interactions. Zoological studies, 58, e35. doi.org/10.6620/ZS.2019.58-35

20. Madhavi, R. \& Lakshmi, T.T. (2011). Metazoan parasites of the Indian mackerel, Rastrelliger kanagurta (Scombridae) of Visakhapatnam coast, Bay of Bengal. Journal of Parasitological Diseases, 35(1), 66-74. doi.org/10.1007/s12639-011-0028-5
21. Madhavi, R. \& Triveni Lakshmi, T. (2012). Community ecology of the metazoan parasites of the Indian mackerel Rastrelliger kanagurta (Scombridae) from the coast of Visakhapatnam, Bay of Bengal. Journal of Parasitological Diseases, 36(2), 165-70. doi.org/10.1007/s12639-0120097-0.

22. Madhavi, R. (2006). Distribution of metacercariae of Centrocestus formosanus (Trematoda: Heterophyidae) on the gills of Aplocheilus panchax. Journal of Fish Biology, 29, 685-690. doi.org/10.1111/j.1095-8649.1986.tb04984.x

23. Margolis, L.G., Esch, W., Holmes, J.C., Kuris, A.M. \& Shad, G.A. (1982). The use of ecological terms in parasitology (report of an ad hoc committee of the American Society of Parasitologists). Journal of Parasitology, 68, 131-133. Retrieved June 2, 2021. http://links.jstor.org/ sici?sici $=00223395 \% 28198202 \% 2968 \% 3$ A $1 \% 3 C 131 \%$ 3ATUOETI\%3E2.0.CO\%3B2-U

24. Mitchell, A.J., Overstreet, R.M., Goodwin, A.E. \& Brandt, T.M. (2005). Spread of an exotic fish-gill trematode: a farreaching and complex problem. Fisheries, 30, 11-16. doi.org/10.1577/1548-8446(2005)30[11:SOAEFT] 2.0.CO;2

25. Mitchell, A.J., Salmon, M.J., Huffman, D.G., Goodwin A. E. \& Brandt T. M. (2000). Prevalence and Pathogenicity of a Heterophyid Trematode infecting the gills of an endangered fish, the Fountain Darter, in Two Central Texas Spring-Fed Rivers. Journal of Aquatic Animal Health, 12 (4),283-289.https://www.sciencebase.gov/catalog/ite $\mathrm{m} / 50576$ efee4b01ad7e027b246

26. Nagasawa, K. \& Shirakashi, S. (2017a). Nerocila phaiopleura, a cymothoid isopod parasitic on Pacific bluefin tuna, Thunnus orientalis, cultured in Japan. Crustacean Research, 46, 95-101. doi: 10.18353/crustacea.46.0_95

27. Nagasawa, K. and S. Isozaki. (2017b). Three new host records for the marine fish ectoparasite, Nerocila phaiopleura (Isopoda: Cymothoidae), with a list of its known hosts. Crustacean Research, 46, 153-159. doi.org/10.183 53/crustacea.46.0_153

28. Nagasawa, K., Nitta, M., Otawa, T. \& Ishikawa, T. (2020). Nerocila phaiopleura (Isopoda: Cymothoidae): a new record from Ibaraki Prefecture, central Japan, with a discussion of its distribution in Japanese waters. Crustacean Research, 49, 41-47. doi.org/10.18353/crustacea.49.0_41

29. Ozer, A. \& Erdem, O. (1998). Ectoparasitic protozoa fauna of the common carp (Cyprinus carpio L., 1758) caught in the Sinop region of Turkey. Journal of Natural History, 32 (3), 441-454. doi.org/10.1080/00222939800770231

30. Paladini, G., Longshaw, M., Gustinelli, A. \& Shinn, A.P. (2017). Parasitic diseases in aquaculture: Their biology, diagnosis and control. In: Diagnosis and Control of Diseases of Fish and Shellfish (pp 37-107). John Wiley \& Sons Ltd, USA.

31. Rameshkumar, G. \& Ravichandran S. (2010). New host record, Rastrelliger kanagurta, for Nerocila phaeopleura parasites (Crustacea, Isopoda, Cymothoidae). MiddleEast Journal of Scientific Research, 5, 54-56. Retrieved June 6, 2021. https://www.idosi.org/mejsr/mejsr5(1)/10.pdf

32. Rameshkumar, G. \& Ravichandran, S. (2013). Effect of the parasitic isopod, Catoessa boscii (Isopoda, Cymothoidae), a buccal cavity parasite of the marine fish, Carangoides malabaricus. Asian Pacific Journal of Tropical Bio- 
medicine, 3(2), 118-122. doi.org/10.1016/S2221-1691(13) 60035-0

33. Ravichandran S. \& Rameshkumar G. (2012). HostParasite Interaction of a Gill-Infecting Didymozoid in the Pazhayar, Southeast Coast of India. World Journal of Fish and Marine Sciences, 4 (1), 60-64. doi.org/10.5829/idosi. wjfms.2012.04.01.6215

34. Ravichandran S. \& Rameshkumar. G. (2014). Effect of parasitic Isopods in commercial marine fishes. Journal of Aquatic Biology and Fisheries, 2, 574-579. Retrieved July 11, 2021. http://keralamarinelife.in/Journals/Vol2-2/91.pdf

35. Ravichandran, S., Sivasubramanian, K., Parasuraman, P., Karthick Rajan, D. \& Ramesh kumar G. Isopod parasite induced secondary microbial infection in marine food fishes. Fish Pathology, 29(1), 1-5. doi.org/10.7847/jfp.2016.2 9.1.001

36. Ravichandran, S., Vigneshwaran, P. \& Rameshkumar, G. (2019). A taxonomic review of the fish parasitic isopod family Cymothoidae Leach, 1818 (Crustacea: Isopoda: Cymothooidea) of India. Zootaxa, 4622(1), 1-99. doi.org/10.11646/zootaxa.4622.1.1

37. Reichenbach-Klinke, H. \& Elkan, E. (1965). The principal diseases of lower vertebrates, Imprint, USA. Retrieved July 11, 2021. https://www.elsevier.com/books/the-princ ipal-diseases-of-lower-vertebrates/reichenbach-klinke/978 $-1-4832-3303-1$

38. Roberts, R.J. (1978). Therapy of fish diseases. In: Fish pathology (pp 268-275). Gateway West (Argyll) Ltd. Ford, Argyll, Scotland, UK.

39. Roberts, R.J. (2012). Fish Pathology. $4^{\text {th }}$ Ed. Blackwell Publishing Ltd, USA. doi.org/10.1002/9781118222942

40. Saha, M. \& Bandyopadhyay, P.K. (2016). Seasonal incidence of protozoan parasitic infestation in ornamental fishes of West Bengal, India. Journal of Parasitic Diseases, 41(2), 523-526. doi.org/10.1007/s12639-016 -0842-x

41. Sethi, S., Jithendran, K.P., \& Kannappan, S. (2013). Coinfection of Yellowtip Halfbeak Fish (Hemiramphus marginatus) with Isopod and Copepod parasites from the Cor- omandal Coast. India Fishery Technology, 50(4), 357360. Retrieved July 10, 2021. http://epubs.icar.org.in/ ejournal/index.php/FT/article/view/34167

42. Sterud, E., Harris, P.H. \& Bake, T.A. (2008). The influence of Gyrodactylus salaris Malmberg 1957 (Monogenea) on the epidermis of Atlantic salmon, Salmo salar L., and brook trout, Salvelinus fontinalis (Mitchill): experimental studies. Journal of Fish Diseases, 21(4), 257-263. doi.org/10.1046/j.1365-2761.1998.00099.x

43. Suliman, E.M., Osman, H.A. \& Al-Deghayem, W.A. (2021). Histopathological changes induced by ectoparasites on gills and skin of Oreochromis niloticus (Burchell 1822 ) in fish. Journal of Applied Biology \& Biotechnology, 9(1), 68-74. doi.org/10.7324/JABB.2021.9109.

44. Tantry, T.A., Nazir, R., Chishti, M.Z., Ahmad, F., Dar, G.H. \& Dar, J.S. (2016). A report on the incidence of Trichodina heterodentata from fishes of Jammu, J\&K India. Journal of Parasitological Diseases, 40(2), 524-527. doi.org/10.100 7/s12639-014-0538-z

45. Trilles, J.P., Rameshkumar, G. \& Ravichandran, S. (2013). Nerocila species (Crustacea, Isopoda, Cymothoidae) from Indian marine fishes. Parasitology Research, 112(3), 1273-1286. doi.org/10.1007/s00436012-3263-5

46. Valladao, G.M.R., Pádua, S.B., Gallani, S.U., MenezesFilho, R.N., Dias-Neto, J., Martins, M.L. \& Pilarski, F. (2013). Paratrichodina africana (Ciliophora): a pathogenic gill parasite in farmed Nile tilapia. Veterinary Parasitology, 197(3-4), 705-710. doi.org/10.1016/j.vetpar.2 013.04.043

47. Woo, P.T.K. (2006). Fish Diseases and Disorders. Protozoan and Metazoan Infections. 2nd Ed. University of Guelph, Canada. Retrieved July 10, 2021. https:// www.cabi.org/bookshop/book/9780851990156/

48. Xu, K., Choi, J.K., Yang, E.J., Lee, K.C. \& Lei, Y. (2002). Biomonitoring of coastal pollution status using protozoan communities with a modified PFU method. Marine Pollution Bulletin, 44(9), 877-886. doi.org/10.1016/S0025-326X (02)00090-5 